Pluto Journals was launched in 2009, as an Independent, Scholarly, and International Journal Publisher in the Social Sciences. All our Journals promote critical thinking in this age of globalization. Our journals include the fields of politics, current affairs, international studies, law, political economy, work, and Arab and Islamic studies.

All our journals are distributed by JSTOR. For subscription information please email:

\section{particiation@jstor.org} Or via your usual agent

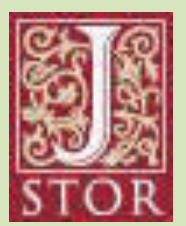

Other Pluto Journals include:

Arab Studies Quarterly State Crime Journal Policy Perspectives ReOrient

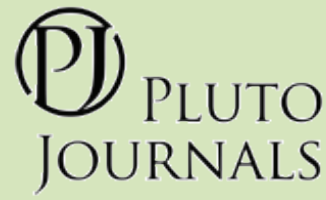

\section{Journal of Global Faultlines}

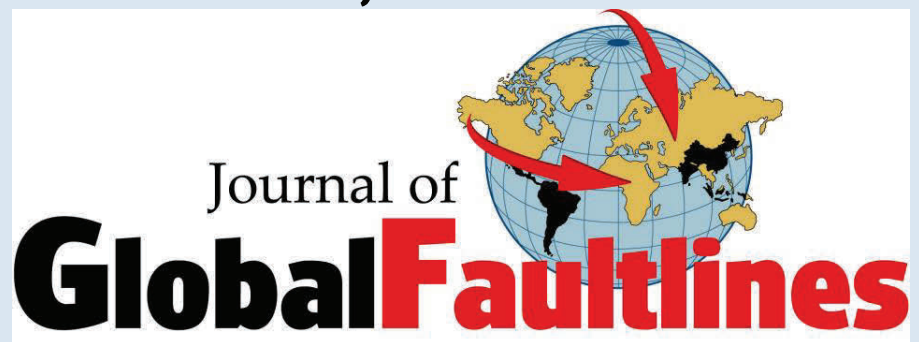

(new in 2017)

ISSN:2054-2089

Our world is on fire. We are living through the epoch of globalization and yet our world could not be more divided, as major 'fault-lines', real or imagined, seem to guide politics at the local and global levels. Things are changing faster than ever in history, and all this leads to severe disruptions. These include global power shifts, dangerous climate change, sharply increased inequalities, financial and economic crises, military interventions, and even wars and civil wars.

Journal of Global Faultlines is an international, peer-reviewed journal that is committed to the critical study of 'fault-lines' and global shifts in world politics. Inspired by the work and approach of the late Andre Gunder Frank, Global Faultlines borrows the geological metaphor of 'tectonic plates' thus offering a unique platform for innovative scholarship on the underlying forces shaping our world in the 21st century. The journal especially encourages interdisciplinary research and original thinking on the issues and processes that seem to divide world politics, but also on the politics of global 'fault-lines' and shifts, that is, on how various perceived demarcations, such as nationalism, civilization and identity, are invoked in contemporary political discourse as well as their social and political effects.

As an interdisciplinary journal we welcome contributions from, and hope to appeal to, the various disciplines and sub-fields in the social sciences and humanities including, but not limited to, Politics, International Relations, Human Geography, Media and Film Studies, English and Literacy Studies, Education Studies, Sociology and Criminology, and Legal Studies.

\title{
Annual Subscription:
}

\section{Please take out a subscription}

Institutions

Institutions online

Individuals

$£ 290$

$£ 250$

$£ 50$

(print and online)

$\begin{array}{ll}\$ 440 & € 400 \\ \$ 375 & € 340\end{array}$

$\$ 75$

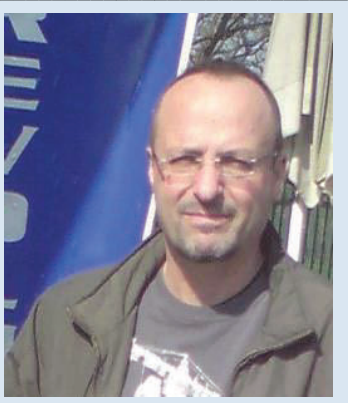

Founding Editor: Professor Bülent Gökay, School of Politics,

Philosophy, International Relations and Environment, Keele University, Keele, Staffordshire, ST5 5BG, +44(0)1782 733512, Email:

b.gokay@keele.ac.uk http://www.keele.ac.uk/spire/staff/gokay/ 